\title{
Cyclic and Square Wave Voltametric Studies of Mn(II) and Co(II) Dithiocarbamate Complexes
}

\author{
Fartisincha P. Andrew and Peter A. Ajibade* \\ School of Chemistry and Physics, University of KwaZulu-Natal, Private Bag X01, Scottsville, \\ Pietermaritzburg, 3209, South Africa \\ *E-mail: ajibadep@ukzn.ac.za
}

doi: $10.20964 / 2021.01 .65$

Received: 2 September 2020 / Accepted: 25 October 2020 / Published: 30 November 2020

The cyclic and square wave voltammetry of $\mathrm{Mn}$ (II) and $\mathrm{Co}(\mathrm{II})$ dithiocarbamate complexes have been investigated. The data obtained indicated one or two redox couple(s), with each redox couple associated with a sequential single electron transfer corresponding to metal center quasi-reversible redox processes. The Manganese(II) complexes ( 1 and 3) exhibited two redox couples in the range -0.4 to $0.6 \mathrm{~V}$, the two oxidations and the corresponding reductions are assigned to $\mathrm{Mn}^{\mathrm{II}} / \mathrm{Mn}^{\mathrm{III}}$ and $\mathrm{Mn}^{\mathrm{III}} / \mathrm{Mn}^{\mathrm{IV}}$ redox processes. The cobalt(II) complexes ( 2 and 4 ) showed a single redox couple in the range 0.52 to $1.12 \mathrm{~V}$, assigned to metal center one-electron quasi-reversible $\mathrm{Co}(\mathrm{II}) /(\mathrm{III})$ and $\mathrm{Co}(\mathrm{III}) /(\mathrm{II})$ oxidation and reduction respectively. The linear relationship of the plot of $I_{p}$, a $v s v^{1 / 2}$ (Randles-Sevcik plot) suggested a diffusion controlled behaviour of all the complexes.

Keywords: Electrochemistry, Dithiocarbamates, Cyclic voltammetry, Manganese(II), Cobalt(II)

\section{FULL TEXT}

(C) 2021 The Authors. Published by ESG (www.electrochemsci.org). This article is an open access article distributed under the terms and conditions of the Creative Commons Attribution license (http://creativecommons.org/licenses/by/4.0/). 